\title{
Deposition of Gadolinia-Doped Zirconia Layers Using Metalorganic Compounds at Low Temperatures
}

\begin{abstract}
Agata Sawka (D)
check for updates

Department of Physical Chemistry and Modelling, Faculty of Materials Science and Ceramics, AGH University of Science and Technology, 30 Mickiewicza Av., 30-059 Krakow, Poland; asawka@agh.edu.pl

Abstract: This paper shows the results of an investigation on the synthesis of non-porous and nanocrystalline $\mathrm{ZrO}_{2}-\mathrm{Gd}_{2} \mathrm{O}_{3}$ layers by metalorganic chemical vapor deposition (MOCVD) with the use of $\mathrm{Zr}$ (tmhd) ${ }_{4}$ (tetrakis(2,2,6,6-tetramethyl-3,5-heptanedionato)zirconium(IV)) and $\mathrm{Gd}(\mathrm{tmhd})_{3}$ (tris(2,2,6,6-tetramethyl-3,5-heptanedionato)gadolinium(III)). Argon and air were used as carrier gases. The molar content of $\mathrm{Gd}(\mathrm{tmhd})_{3}$ in the gas reaction mixture was as follows: $10 \%$ and $20 \%$. The layers were synthesized on tubular substrates made of quartz glass at the temperatures of 550-700 ${ }^{\circ} \mathrm{C}$. Synthesis conditions were established using the $\mathrm{Gr}_{\mathrm{x}} / \operatorname{Re}_{\mathrm{x}}{ }^{2}$ expression (Gr is the Grashof number; Re is the Reynolds number; $\mathrm{x}$ is the distance from the gas inflow point). The value of this criterion was below $0.01 . \mathrm{ZrO}_{2}-\mathrm{Gd}_{2} \mathrm{O}_{3}$ layers synthesized at $600-700{ }^{\circ} \mathrm{C}$ were crystalline. When the molar content of $\mathrm{Gd}(\mathrm{tmhd})_{3}$ in the gas reaction mixture was $10 \mathrm{~mol} \%$, a relationship between the chemical composition of the gas reaction mixture and that of the deposited layer could be observed. The synthesized layers underwent scanning electron microscopy, as well as X-ray analysis. The transparency of coated and uncoated glass was tested using UV-Vis spectroscopy. Their chemical composition was examined with the use of an EDS analyzer.
\end{abstract}

Citation: Sawka, A. Deposition of Gadolinia-Doped Zirconia Layers Using Metalorganic Compounds at Low Temperatures. Materials 2021, 14, 7573. https://doi.org/10.3390/ ma14247573

Academic Editor:

Gueorgui Gueorguiev

Received: 29 October 2021

Accepted: 6 December 2021

Published: 9 December 2021

Publisher's Note: MDPI stays neutral with regard to jurisdictional claims in published maps and institutional affiliations.

Copyright: (c) 2021 by the author. Licensee MDPI, Basel, Switzerland. This article is an open access article distributed under the terms and conditions of the Creative Commons Attribution (CC BY) license (https:// creativecommons.org/licenses/by/ $4.0 /)$.
Keywords: gadolinia-doped zirconia layers; MOCVD method; thermal barrier coatings (TBC)

\section{Introduction}

$\mathrm{ZrO}_{2}-\mathrm{Gd}_{2} \mathrm{O}_{3}$ system materials exhibit very promising electrical, optical, thermal, and mechanical properties. They are characterized by good ionic conductivity, which means that they can be applied as an electrolyte in solid oxide fuel cells [1-11]; they can emit narrow bands in the UV-B region, which influences the luminescence properties of this material [12]; and they have high radiation resistance and therefore can be used, for example, in the immobilization of nuclear waste products generated in nuclear reactor fuel [13].

Gadolinium zirconate and gadolinia-doped zirconia also seem to be promising materials for applications in thermal barrier coatings (TBCs) as a top coat [14-32]. Gadolinium zirconate has very low thermal conductivity, a high melting point (above $2000{ }^{\circ} \mathrm{C}$ ), and its phase transformation temperatures are higher than those of yttria-stabilized zirconia [30]. $\mathrm{Gd}_{2} \mathrm{Zr}_{2} \mathrm{O}_{7}$ is stable at $1500-1550{ }^{\circ} \mathrm{C}[17,25,28]$. It is also characterized by excellent chemical resistance to $\mathrm{CaO}-\mathrm{MgO}-\mathrm{Al}_{2} \mathrm{O}_{3}-\mathrm{SiO}_{2}$ (CMAS) attack $[17,20,22,26,28,30]$. Its disadvantage is, however, a reduced fracture toughness, which leads to easy crack formation and lower erosion resistance [25,26]. However, it seems [32] that the addition of $\mathrm{YbSZ}\left(\mathrm{Yb}_{2} \mathrm{O}_{3}\right.$-stabilized $\mathrm{ZrO}_{2}$ ) to $\mathrm{Gd}_{2} \mathrm{Zr}_{2} \mathrm{O}_{7}$ could improve its fracture toughness. $\mathrm{Gd}_{2} \mathrm{Zr}_{2} \mathrm{O}_{7}$ coatings for TBC applications are deposited mainly using methods such as atmospheric plasma spraying (APS) [16,22,27], electron beam physical vapor deposition (EB PVD), [19,24,26,28,30], or suspension plasma spraying (SPS) [20]. Attempts to obtain $\mathrm{Gd}_{2} \mathrm{Zr}_{2} \mathrm{O}_{7}$ coatings were undertaken using the metalorganic chemical vapor deposition (MOCVD) method $[17,18]$. The manufacturing and the properties of $\mathrm{Gd}_{2} \mathrm{Zr}_{2} \mathrm{O}_{7}$ coatings have been studied extensively for many years; however, investigations on the synthesis of $\mathrm{Gd}_{2} \mathrm{O}_{3}$-doped $\mathrm{ZrO}_{2}$ layers have been significantly less developed. 
$\mathrm{Gd}_{2} \mathrm{O}_{3}$ is considered an alternative stabilizer to $\mathrm{Y}_{2} \mathrm{O}_{3}$ in $\mathrm{ZrO}_{2}$-based materials applied in TBCs as a top coat. Yttria-stabilized zirconia is conventionally used in TBCs. There are three polymorphic phases of $\mathrm{ZrO}_{2}$ : monoclinic, tetragonal, and cubic. The addition of 7 to $8 \mathrm{wt}$ \% (4 to $4.5 \mathrm{~mol} . \%$ ) $\mathrm{Y}_{2} \mathrm{O}_{3}$ (4YSZ) allows for the stabilization of the tetragonal prime $\left(t^{\prime}\right)$ phase. This is the most advantageous phase for these applications due to its low thermal conductivity and high fracture toughness. The use of the $\mathrm{t}^{\prime}-\mathrm{ZrO}_{2}$ phase in TBC s can produce a longer thermal cycle life than is possible in the case of the cubic phase $[31,33]$. However, it undergoes decomposition into high and low yttria phases upon prolonged exposure at elevated temperatures. After cooling, these second phases transform into the monoclinic phase, which is accompanied by an increase in its volume and can lead to the destruction of TBCs. Their acceptable application temperature is $1200{ }^{\circ} \mathrm{C}$. The next limitation of their use is the sintering process, which can lead to a reduction of their high-temperature capability and a loss of their strain tolerance $[33,34]$.

In a study [14], $\mathrm{Gd}_{2} \mathrm{O}_{3}$-stabilized $\mathrm{ZrO}_{2}$ coatings were obtained using plasma spraying (PS). The addition of 4 mol. $\%$ of $\mathrm{Gd}_{2} \mathrm{O}_{3}$ led to a slower sintering process of $\mathrm{Gd}_{2} \mathrm{O}_{3}$-stabilized $\mathrm{ZrO}_{2}$ top coat and a lower thermal conductivity than $\mathrm{Y}_{2} \mathrm{O}_{3}$-stabilized $\mathrm{ZrO}_{2}$. However, it had a lower resistance to the destabilization of the metastable tetragonal $\left(\mathrm{t}^{\prime}\right)$ phase than yttria-stabilized zirconia. It appears that further research is needed to solve this problem.

The aim of this study was to obtain non-porous, nanocrystalline, $\mathrm{Gd}_{2} \mathrm{O}_{3}$-doped $\mathrm{ZrO}_{2}$ layers using MOCVD. The presence of pores in materials reduces their thermal conductivity but, on the other hand, acts as stress concentrators in materials. Moreover, pores allow for the easy penetration of CMAS into the substrate. Hence, they are characterized by low resistance to thermal stresses. Their non-porous and nanocrystalline microstructure should assure their low thermal conductivity, as well as high mechanical strength. Investigations on the influence of nanostructured microstructure of a top coat on TBC properties were conducted for yttria-stabilized zirconia coatings [34]. It was found that the nanocrystalline coatings of yttria-stabilized zirconia could significantly improve the performance of TBCs. It is thought that nanostructured yttria-stabilized zirconia exhibits excellent thermal insulation capability and durability at high temperatures. The reduced thermal conductivity is a result of the scattering of phonons at the grain boundaries of nanocrystalline material. Thus, the coatings could be very thin, ensuring low component weight. It was also observed that the thermal conductivity of nanocrystalline yttria-stabilized zirconia coating was about $15 \%$ lower than in the case of microcrystalline material. Investigation into the resistance to thermal shocks of nanocrystalline $\mathrm{Y}_{2} \mathrm{O}_{3}$-stabilized $\mathrm{ZrO}_{2}$ coatings demonstrated that the number of thermal shock cycles due to material failure was about two to three times higher than for conventional microcrystalline coating. It was also noted [21] that nanostructured yttria-stabilized zirconia coatings demonstrated better resistance against oxidation and hot corrosion than conventional ones. Moreover, nanocrystalline coatings contained fewer microcracks. It should be mentioned that nanocrystalline yttria-stabilized zirconia coatings have been deposited by the APS method [21,34], and coatings manufactured with its usage are usually characterized by high porosity and low mechanical strength. Such studies have not been carried out in the case of $\mathrm{Gd}_{2} \mathrm{O}_{3}$-stabilzed $\mathrm{ZrO}_{2}$ synthesized by MOCVD. However, it seems that the deposition of non-porous and nanocrystalline $\mathrm{Gd}_{2} \mathrm{O}_{3}$-stabilized $\mathrm{ZrO}_{2}$ layers with the use of this technique should also be advantageous and significantly improve the performance of TBCs.

This paper presents the results of research on the microstructure, structure, and chemical composition of $\mathrm{Gd}_{2} \mathrm{O}_{3}$-doped $\mathrm{ZrO}_{2}$ layers synthesized by MOCVD onto substrates of complex shape.

\section{Materials and Methods}

$\mathrm{Gd}_{2} \mathrm{O}_{3}$-doped $\mathrm{ZrO}_{2}$ layers were obtained by the MOCVD method with the use of $\mathrm{Zr}$ (tmhd) ${ }_{4}$ (tetrakis(2,2,6,6-tetramethyl-3,5-heptanedionato)zirconium(IV)) (Aldrich, Saint Louis, MO, USA) and Gd(tmhd)3 (tris(2,2,6,6-tetramethyl-3,5-heptanedionato)gadolinium(III)) 
(Alfa Aesar, Haverhill, MA, USA) as reactants. Argon, as well as air, were used as carrier gases. For carbon elimination during the layer growth, air was used.

The deposition temperature was in the range of $550-700{ }^{\circ} \mathrm{C}$. Pressure was in the range of $5 \times 10^{2}-6 \times 10^{3} \mathrm{~Pa}$. The deposition time was 10-30 min. The evaporation temperature of $\mathrm{Zr}(\mathrm{tmhd})_{4}$ was changed from 260 to $280^{\circ} \mathrm{C}$, and in the case of $\mathrm{Gd}(\mathrm{tmhd})_{3}$, from 170 to $190{ }^{\circ} \mathrm{C}$. Reactants were weighed and the amounts were chosen to ensure their appropriate molar ratio. Due to differences in their evaporation temperatures, a special original evaporator was designed, which was placed in the furnace with gradient temperature distribution. This ensured an appropriate evaporation temperature for each of the reactants. This solution ensured a constant molar ratio of reactants. Their vapors were transported to the CVD (chemical vapor deposition) reactor by pure argon (the molar ratio of reactants was constant). The molar content of $\mathrm{Gd}(\mathrm{tmhd})_{3}$ in the gas reaction mixture was $10 \%$ or $20 \%$.

The magnitude of the $\mathrm{Gr}_{\mathrm{x}} / \mathrm{Re}_{\mathrm{x}}{ }^{2}$ expression was less than 0.01 (Gr is the Grashof number; Re is the Reynolds number; $x$ is the distance from the gas inflow point) [35-37]. The use of this criterion is helpful in the synthesis of dense and uniform-thickness layers. The deposition parameters selected using this expression allow for the prevention of the homogeneous nucleation process during layer growth. It includes factors such as chemical reactions, heating of cold gases by a hot substrate, irregular shape of the reactor, and mode of gas waste removal. Low $\mathrm{Gr}_{x} / \mathrm{Re}_{\mathrm{x}}{ }^{2}$ values favor elimination of the homogeneous nucleation, and allow the production of uniformly thick layers on large substrates with complicated shapes [35]. A diagram of MOCVD equipment is shown in [38].

$\mathrm{ZrO}_{2}-\mathrm{Gd}_{2} \mathrm{O}_{3}$ layers were deposited on the inner surfaces of tubular substrates. Commercial tubes were made of quartz glass $\left(\Phi_{\text {external }}=14 \mathrm{~mm}\right.$, $\Phi_{\text {internal }}=13 \mathrm{~mm}$, and L $=25 \mathrm{~mm}$ ). Quartz glass substrates were used as substitute substrates. The main advantages of their use are the easy observation and assessment of the obtained layers due to the transparency of the substrates, and their low cost $[36,37,39]$.

Surfaces and cross-sections of synthesized layers were examined with the use of a scanning electron microscope (SEM NANO NOVA 200) produced by FEI EUROPE COMPANY (Eindhoven, The Netherlands), and an energy dispersive $X$-ray spectroscope (EDS) microanalyzer manufactured by EDAX EDS Company (Mahwah, NJ, USA). X-ray diffraction analyses were performed with the use of an X'Pert X-ray diffractometer from Panalytical (Malvern, UK). The transparency tests of coated and uncoated glass were carried out using a UV-Vis Spectrophotometer JASCO V630 from JASCO Deutschland GmbH (Pfungstadt, Germany).

\section{Results and Discussion}

Deposited layers were visually transparent and without white powders. This means that during layer growth, homogeneous nucleation did not occur. Products of homogeneous nucleation are formed in the gas phase and are in the form of porous solid particles. Larger particles settling on the deposited layers disturb their microstructure and deteriorate their properties. Furthermore, the layers are characterized by poor adhesion to the substrate and by lower mechanical strength and corrosive resistance. Their presence reduces their transparency when the deposited layers are amorphous.

Figure 1 presents an example of a $\mathrm{ZrO}_{2}-\mathrm{Gd}_{2} \mathrm{O}_{3}$ layer obtained at a temperature of $550{ }^{\circ} \mathrm{C}$. The molar content of $\mathrm{Gd}(\mathrm{tmhd})_{3}$ in the gas reaction mixture was $10 \%$. The results from Figure $1 \mathrm{~b}$ show that the layer was non-porous and uniform in thickness (about $200 \mathrm{~nm}$ ). The layer growth rate was about $400 \mathrm{~nm} / \mathrm{h}$. EDS point analysis was performed at two different points of the layer (Figure 1a confirms the presence of $\mathrm{Zr}$ and Gd in the layer (Table 1)). 


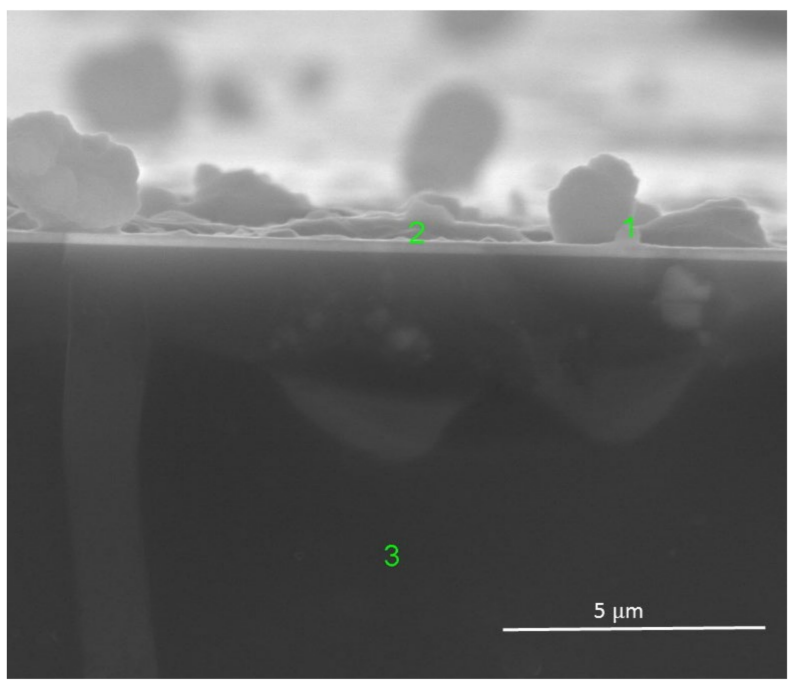

(a)

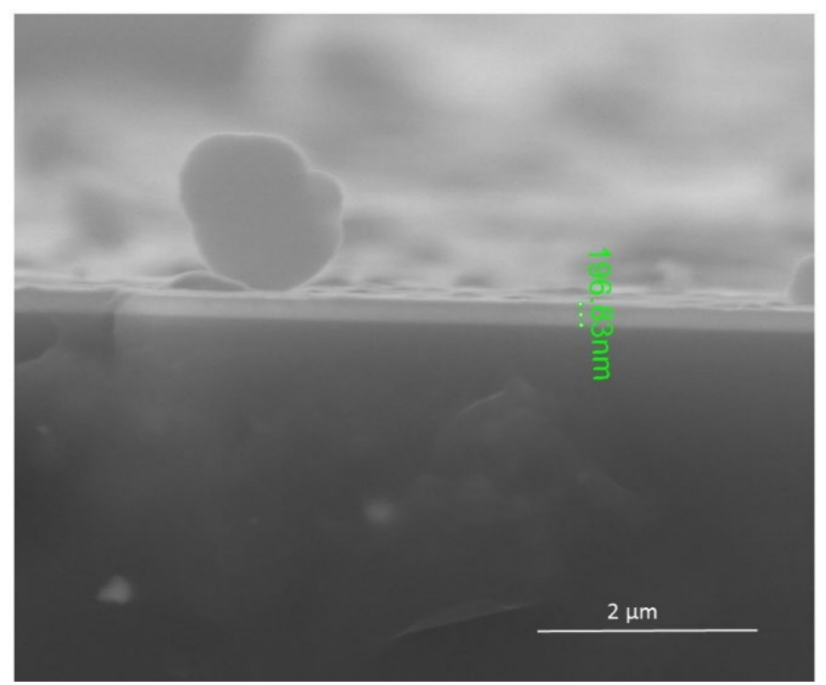

(b)

Figure 1. $\mathrm{ZrO}_{2}-\mathrm{Gd}_{2} \mathrm{O}_{3}$ layer deposited at $550{ }^{\circ} \mathrm{C}$ (surface and cross-section) (a) and its thickness (b). Molar content of $\mathrm{Gd}(\mathrm{tmhd})_{3}$ in the gas reaction mixture: $10 \%$. Synthesis time: $30 \mathrm{~min}$.

Table 1. Average chemical composition carried out by EDS point analysis at points 1 and 2 presented in Figure 1a.

\begin{tabular}{|c|c|c|c|c|c|}
\hline $\begin{array}{c}\text { Point } \\
\text { Number }\end{array}$ & Element & $\begin{array}{c}\text { Weight } \\
\text { (\%) }\end{array}$ & $\begin{array}{c}\text { Atomic } \\
(\%)\end{array}$ & $\begin{array}{c}\text { Expected Molar } \\
\text { Content of } \mathrm{Gd}_{2} \mathrm{O}_{3} \\
\text { in the Layer }(\%)\end{array}$ & $\begin{array}{c}\text { Calculated Molar } \\
\text { Content of } \mathrm{Gd}_{2} \mathrm{O}_{3} \\
\text { in the Layer }(\%)\end{array}$ \\
\hline \multirow{2}{*}{ Point 1} & $\mathrm{Zr}$ & 22.45 & 5.57 & \multirow{2}{*}{5} & \multirow{2}{*}{4.54} \\
\hline & $\mathrm{Gd}$ & 3.66 & 0.53 & & \\
\hline \multirow{2}{*}{ Point 2} & $\mathrm{Zr}$ & 22.98 & 5.82 & \multirow{2}{*}{5} & \multirow{2}{*}{6.58} \\
\hline & $\mathrm{Gd}$ & 5.55 & 0.82 & & \\
\hline
\end{tabular}

Calculations of the molar content of $\mathrm{Gd}_{2} \mathrm{O}_{3}$ in the layers indicated that there was a relationship between the chemical composition of the gas reaction mixture used and the composition of the layer deposited. If the molar content of $\mathrm{Gd}(\mathrm{tmhd})_{3}$ in the gas reaction mixture was $10 \%$, the content of $\mathrm{Gd}_{2} \mathrm{O}_{3}$ in the layer should amount to about 5 mol.\%. By analyzing the data in Table 1, it seems that these results are in line with expectations. This also means that the process of the layer deposition was controlled by the diffusion of reactants to the substrate. Subsequently, the value of the fraction of substrate (layer) surface available for the adsorption of reactants and solid reaction products $\left(1-\Theta_{z}\right.$, where $\Theta_{z}$ is the surface fraction, where there is adsorption) may be large, and the reactant concentration $\mathrm{p}_{\mathrm{i}(\mathrm{s})}$ on the substrate surface is close to zero [35,40]. When the synthesis is controlled by the surface reaction rate, then the concentration of the reactants used on the substrate $\mathrm{p}_{\mathrm{i}(\mathrm{s})}$ is greater than zero and the reactant adsorption can be more intensive. Hence, competition in adsorption can occur between these reactants. For this reason, there is a difference between the molar contents of reactants supplied to the CVD (MOCVD) reactor and those adsorbed on the substrate surface $[35,40]$.

The surface of the layer was also synthesized at $550{ }^{\circ} \mathrm{C}$, but with a higher molar content of $\mathrm{Gd}(\mathrm{tmhd})_{3}$, i.e., $20 \%$ as shown in Figure 2. 


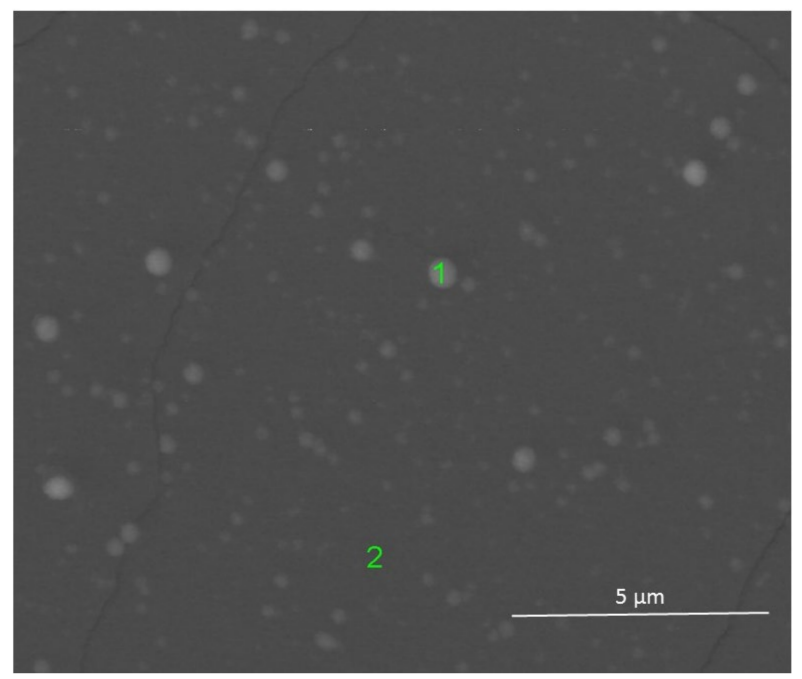

(a)

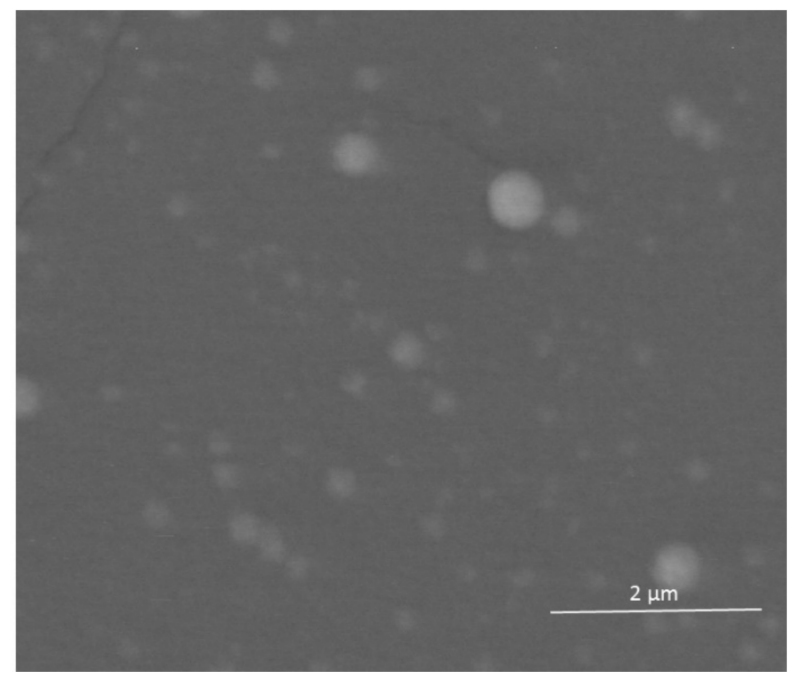

(b)

Figure 2. $\mathrm{ZrO}_{2}-\mathrm{Gd}_{2} \mathrm{O}_{3}$ layer deposited at $550{ }^{\circ} \mathrm{C}$. Magnification: $\times 20,000$ (a) and magnification: $\times 40,000$ (b). Molar content of $\mathrm{Gd}(\mathrm{tmhd})_{3}$ in the gas reaction mixture: $20 \%$. Synthesis time: $30 \mathrm{~min}$.

The layer was also non-porous and contained $\mathrm{Zr}$ and Gd (Table 2).

Table 2. Average chemical composition carried out by EDS point analysis at points 1 and 2 presented in Figure 2a.

\begin{tabular}{cccccc}
\hline $\begin{array}{c}\text { Point } \\
\text { Number }\end{array}$ & Element & $\begin{array}{c}\text { Weight } \\
\mathbf{( \% )}\end{array}$ & $\begin{array}{c}\text { Atomic } \\
\mathbf{( \% )}\end{array}$ & $\begin{array}{c}\text { Expected Molar } \\
\text { Content of } \mathrm{Gd}_{\mathbf{2}} \mathbf{O}_{\mathbf{3}} \\
\text { in the Layer (\%) }\end{array}$ & $\begin{array}{c}\text { Calculated Molar } \\
\text { Content of } \mathrm{Gd}_{\mathbf{2}} \mathbf{O}_{\mathbf{3}} \\
\text { in the Layer (\%) }\end{array}$ \\
\cline { 1 - 4 } Point 1 & $\mathrm{Zr}$ & 30.51 & 10.92 & 10 & 15.08 \\
\cline { 2 - 4 } Point 2 & $\mathrm{Gd}$ & 18.69 & 3.88 & & 11.92 \\
\cline { 2 - 4 } & $\mathrm{Zr}$ & 31.97 & 11.82 & 10 & \\
\hline
\end{tabular}

EDS point analysis at point 1 (brighter surface) and at point 2 (darker surface) also allowed us to ascertain that, especially in the case of point 1, the amount of dopant in the layer was overstated (it should be about $10 \mathrm{~mol} . \%$, but was about $15 \mathrm{~mol} . \%$ ). At point 2, this value amounted to about $12 \mathrm{~mol} \%$. Most likely, the process of the layer deposition was controlled by the surface reaction rate. There was a large differentiation in the reactant adsorption on the substrate as a function of the temperature and the reactant concentration. The use of a high dilution of the reactants in the carrier gases, and/or the reduction of the diffusion coefficients of reactants, can cause a decrease in the transition temperature from the synthesis controlled by the reaction rate to that controlled by mass diffusion to the substrate from the gas phase.

It is also supposed that the difference in the molar contents of dopant in the layer was likely a result of the occurrence of $\mathrm{Zr}^{4+}$ ion segregation; $\mathrm{Zr}^{4+}$ has a smaller ionic radius than $\mathrm{Gd}^{3+}$ ions (the ionic radius of $\mathrm{Zr}^{4+}$ is $0.84 \AA$ and that of $\mathrm{Gd}^{3+}$ is $0.934 \AA$ ). Their segregation takes place from more ordered areas (brighter surface) to less ordered areas (darker surface). A similar phenomenon was observed in [41]. Furthermore, the layer likely includes aggregates consisting of nanocrystallites. However, X-ray analysis (Figure 3) showed that the deposited layer was amorphous. 


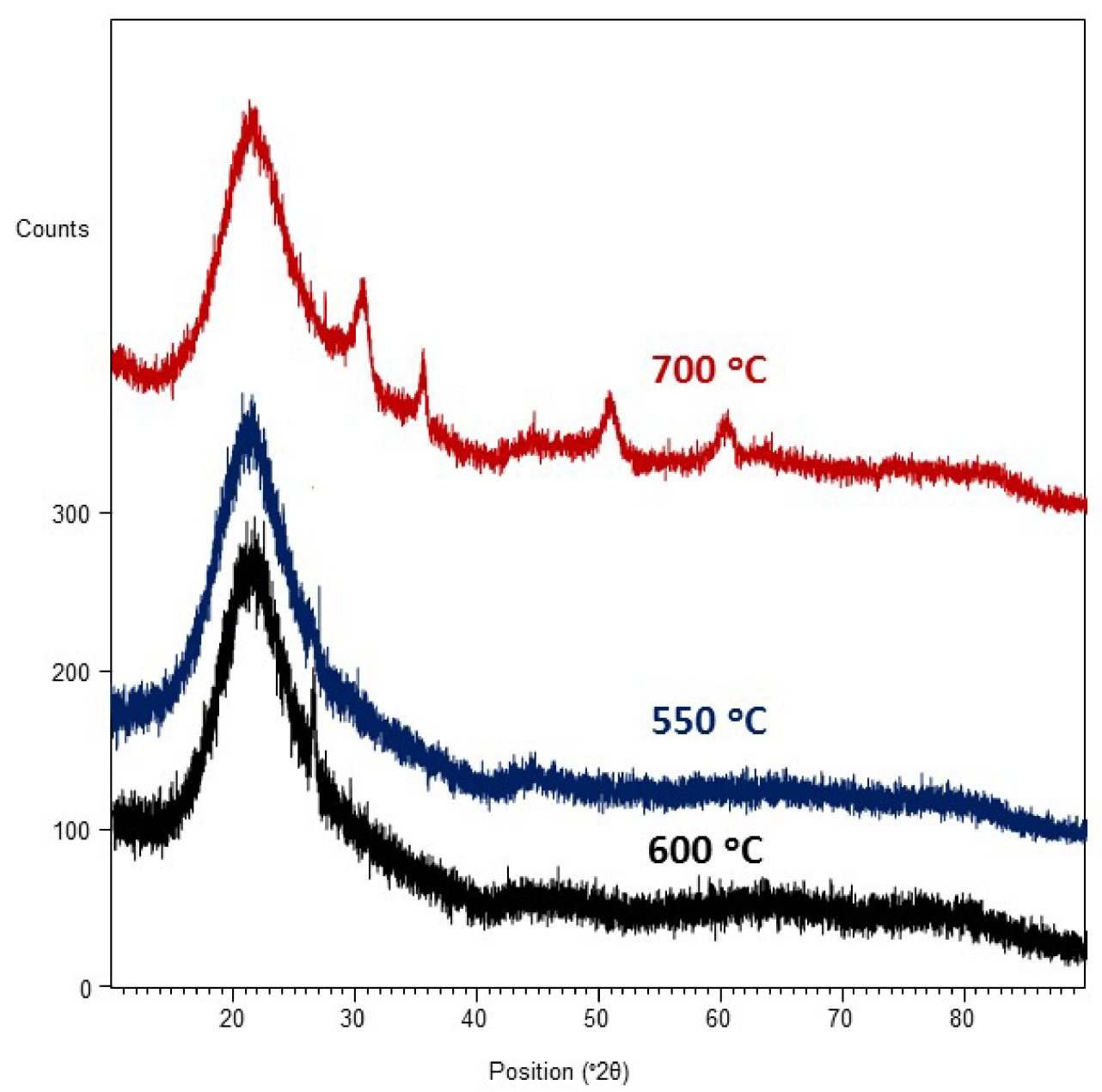

Figure 3. X-ray diffraction pattern of $\mathrm{ZrO}_{2}-\mathrm{Gd}_{2} \mathrm{O}_{3}$ layers deposited at 550,600 , and $700{ }^{\circ} \mathrm{C}$. Molar content of $\mathrm{Gd}(\mathrm{tmhd})_{3}$ in the gas reaction mixture: $10 \%$.

It should also be noted that the layers were synthesized on commercial substrates. Due to the presence of unmelted glass sand in quartz glass, the substrate surface was not smooth. Defects on a glass surface are in the form of convexities. The coordination number of atoms on these surface parts is smaller. Hence, more intensive adsorption of reactants can occur there than on planar parts of the glass substrate. At higher temperatures, it can also be the reason for the presence of a greater number of grain forms in the layer.

In Figure 4a, the results show that the layer deposited was also non-porous and uniform in thickness. The layer was synthesized at a temperature of $600{ }^{\circ} \mathrm{C}$ with $10 \mathrm{~mol} . \%$ content of $\mathrm{Gd}(\mathrm{tmhd})_{3}$. It seems that the beginnings of its crystallization were already visible (Figure 3 ). Numerous aggregates were also present on its surface (Figure 4a). From the linear EDS analysis (Figure $4 \mathrm{~b}$ ), the results showed that the layer contained $\mathrm{Zr}$ as well as $\mathrm{Gd}$.

Figure 5 shows the surface and the cross-section of the layer deposited at the same temperature, but when the molar content of $\mathrm{Gd}(\mathrm{tmhd})_{3}$ was $20 \%$. The synthesis time was $15 \mathrm{~min}$. The deposited layer had no pores and was uniform in thickness (Figure 5a). EDS analysis confirmed the presence of $\mathrm{Zr}$ and Gd in the obtained layer (Figure 5b). Most likely, the presence of carbon in the layer (Figure $5 \mathrm{c}$ ) was due to the fact that the samples had to be sputtered with carbon before SEM and EDS tests. Despite the layer being thinner (the synthesis time was twice as short), numerous aggregates were visible on its surface.

In Figure 6, the surface and cross-section of the layer, deposited at $700{ }^{\circ} \mathrm{C}$ are shown. The layer had a thickness of about $235 \mathrm{~nm}$, was without pores, and was uniform (Figure $6 \mathrm{~b}$ ). The layer growth rate was about $470 \mathrm{~nm} / \mathrm{h}$. This growth rate is slightly different from that of the layers deposited at a temperature of $550{ }^{\circ} \mathrm{C}$. 
The results of the EDS point analysis carried out at point 1 (Figure 6a) are in alignment with the expectations for quality and quantity (Table 3).

Table 3. Average chemical composition performed by EDS point analysis at point 1 shown in Figure 6a.

\begin{tabular}{cccccc}
\hline $\begin{array}{c}\text { Point } \\
\text { Number }\end{array}$ & Element & $\begin{array}{c}\text { Weight } \\
(\%)\end{array}$ & $\begin{array}{c}\text { Atomic } \\
(\%)\end{array}$ & $\begin{array}{c}\text { Expected Molar } \\
\text { Content of } \mathrm{Gd}_{2} \mathrm{O}_{3} \\
\text { in the Layer (\%) }\end{array}$ & $\begin{array}{c}\text { Calculated Molar } \\
\text { Content of } \mathrm{Gd}_{2} \mathrm{O}_{3} \\
\text { in the Layer }(\%)\end{array}$ \\
\cline { 1 - 4 } Point 1 & $\mathrm{Zr}$ & 31.35 & 8.81 & 5 & 5.37 \\
\cline { 2 - 4 } & $\mathrm{Gd}$ & 6.15 & 1.00 & & 5.37 \\
\hline
\end{tabular}

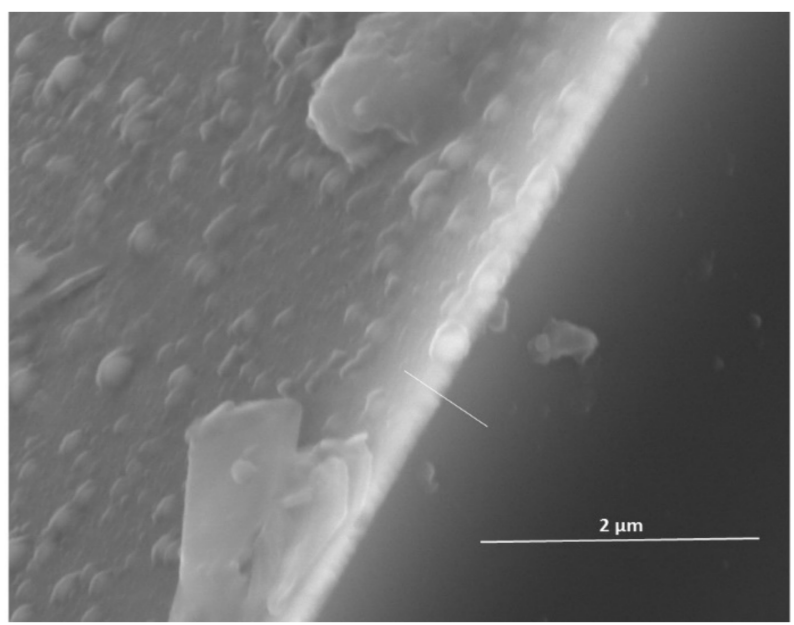

(a)

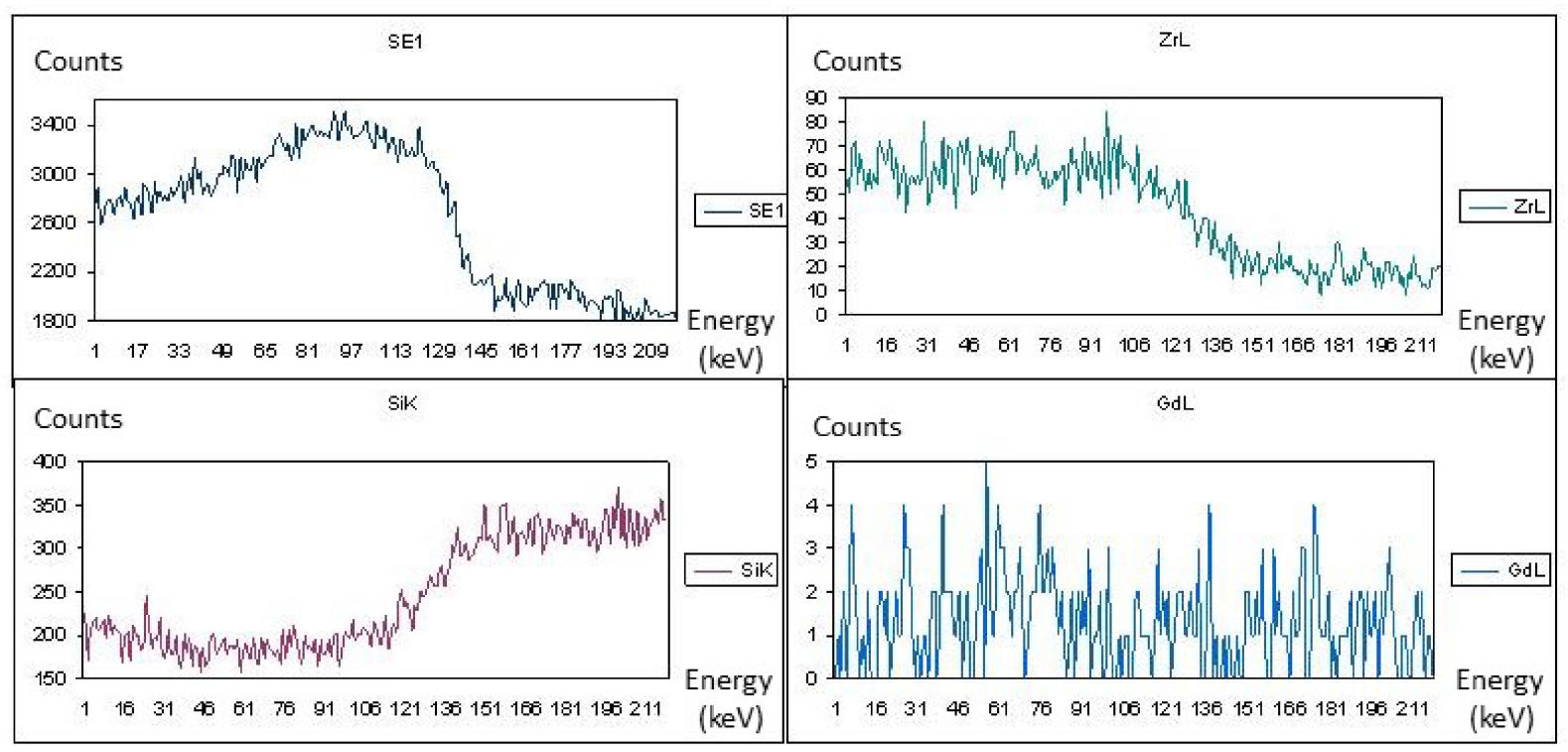

(b)

Figure 4. $\mathrm{ZrO}_{2}-\mathrm{Gd}_{2} \mathrm{O}_{3}$ layer deposited at $600{ }^{\circ} \mathrm{C}$ (its surface and cross-section) (a), with linear EDS analysis (b). Molar content of $\mathrm{Gd}(\mathrm{tmhd})_{3}$ in the gas reaction mixture: $10 \%$. Synthesis time: $30 \mathrm{~min}$. 


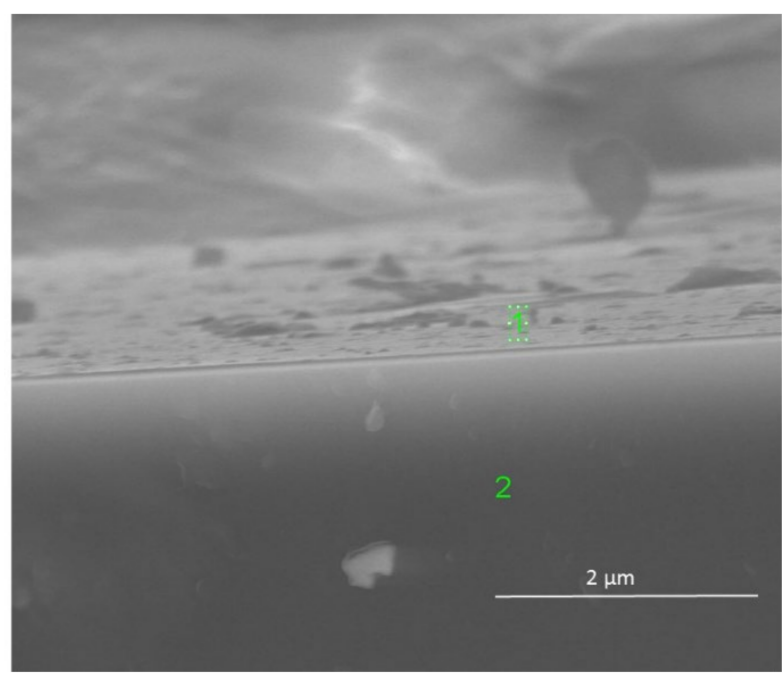

(a)

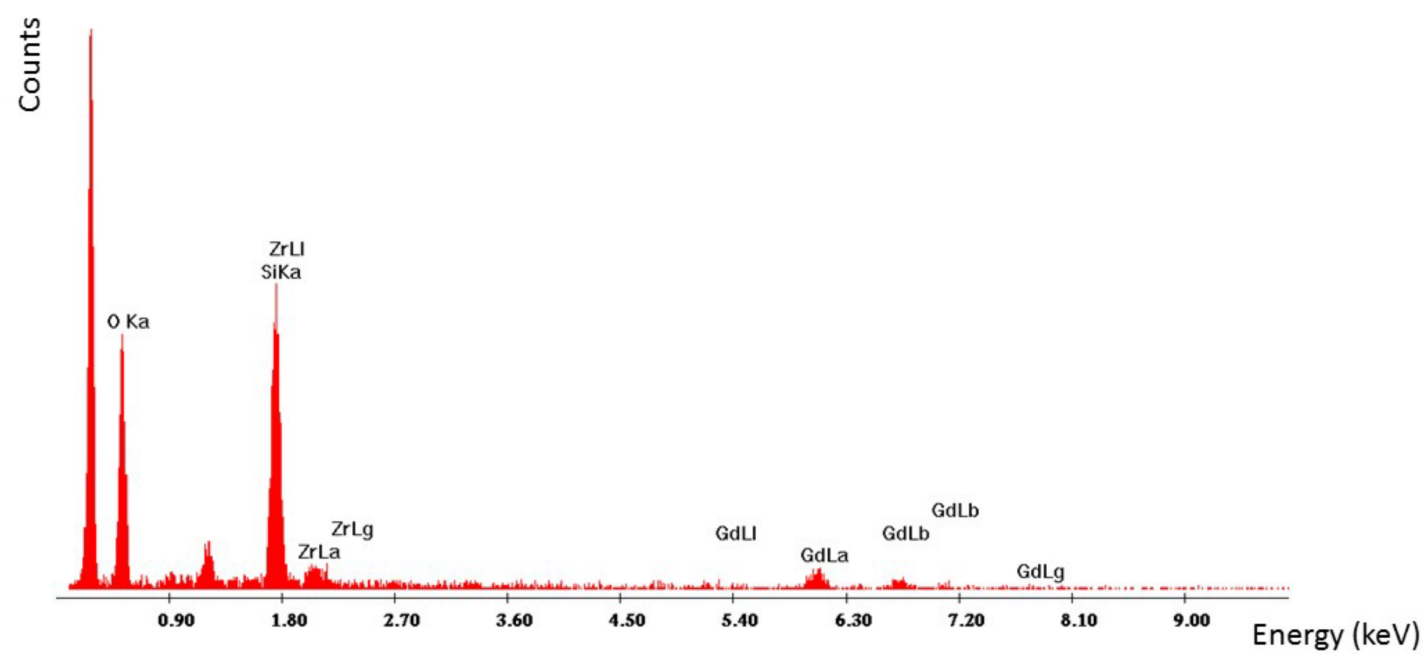

(b)

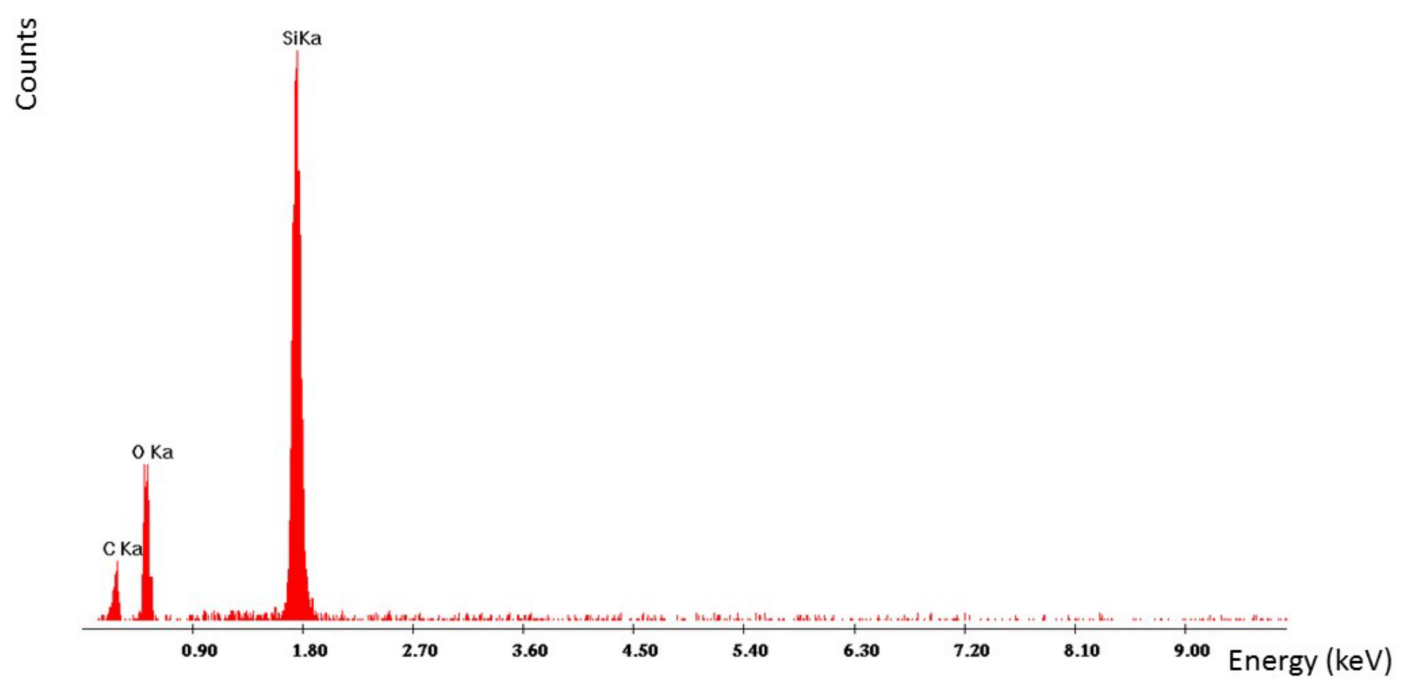

(c)

Figure 5. $\mathrm{ZrO}_{2}-\mathrm{Gd}_{2} \mathrm{O}_{3}$ layer deposited at $600{ }^{\circ} \mathrm{C}$ (its surface and cross-section) (a), with EDS analysis at point 1 (b) and point 2 (c). Molar content of $\mathrm{Gd}(\mathrm{tmhd})_{3}$ in the gas reaction mixture: $20 \%$. Synthesis time: $15 \mathrm{~min}$. 


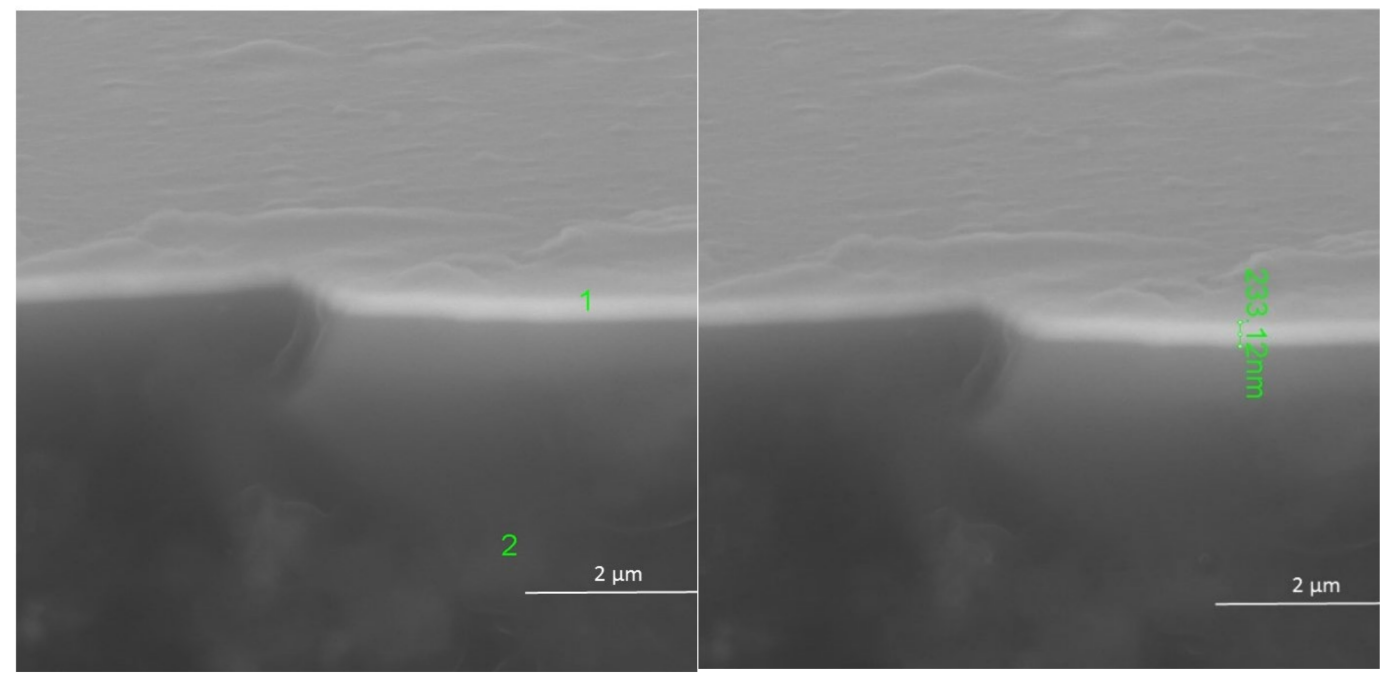

(a)

(b)

Figure 6. $\mathrm{ZrO}_{2}-\mathrm{Gd}_{2} \mathrm{O}_{3}$ layer deposited at $700{ }^{\circ} \mathrm{C}$ (its surface and cross-section) (a) and its thickness (b). Molar content of $\mathrm{Gd}(\mathrm{tmhd})_{3}$ in the gas reaction mixture: $10 \%$. Synthesis time was $30 \mathrm{~min}$.

It is possible that the process of the layer synthesis was controlled by mass diffusion to the substrate. This also means that the chemical composition of the layers deposited could be controlled under these synthesis conditions. In this case, the concentration of the reactants on the substrate surface was lower, and competition in the adsorption between both reactants did not occur. This competition depends on the concentration of the reactant used in the gas phase and the substrate temperature. The Figure 3 results show that the layer was crystalline (Figure 3). This was a solid solution of $\mathrm{Gd}_{2} \mathrm{O}_{3}$ in $\mathrm{ZrO}_{2}$.

A cross-section of the layer obtained at $700{ }^{\circ} \mathrm{C}$, but with $20 \mathrm{~mol} . \%$ content of $\mathrm{Gd}(\mathrm{tmhd})_{3}$ in the reaction mixture, is presented in Figure 7. However, in this case, the synthesis time was shorter than previous ones; it was $15 \mathrm{~min}$. The layer thickness was about $111 \mathrm{~nm}$ (Figure 7c). In this case, the layer growth rate was about $440 \mathrm{~nm} / \mathrm{h}$. This finding confirmed that the layer growth rate was constant. The layer growth rate can be independent of the temperature, when other synthesis conditions are appropriately selected. As mentioned, the synthesis conditions were established so that $\mathrm{Gr}_{x} / \operatorname{Re}_{x}{ }^{2}$ did not exceed 0.01 [35-37]. If the synthesis temperature is higher, the reactant concentration should be lower. The amount of reactants would remain the same, but the amount of diluent gas (e.g., argon) should be higher.

From linear EDS analysis (Figure $7 \mathrm{~b}$ ), it can be seen that $\mathrm{Zr}$ and $\mathrm{Gd}$ were present in the obtained layer.

In order to check whether the homogeneous nucleation process was present during the layer growth, the transparency tests of coated and uncoated substrates were performed (Figure 8). In Figure 8, the results show that the transparency of amorphous layers was similar to that of uncoated quartz glass. When the layers became crystalline, their transparency decreased. This appears to be a consequence of light scattering at the grain boundaries. A similar situation was observed in other studies [37,40]. However, when the layer was obtained at $550{ }^{\circ} \mathrm{C}$ with $10 \mathrm{~mol} . \%$ content of $\mathrm{Gd}(\mathrm{tmhd})_{3}$ in the gas reaction mixture (yellow line), a decrease in its transparency was observed above about $750 \mathrm{~nm}$. As mentioned, the layers were synthesized on commercial tubes made of quartz glass and were synthesized on their inner surfaces. The curved shape of the substrates was a reason for measurement difficulties. It should also be noted that this commercial glass showed some roughness that was caused by the presence of unmelted sand fragments on its surface. The layers are able to be deposited easier on the unevenness of the substrate due to a higher energy of the convex surface (coordination number of atoms on this surface is subsequently lower). On its uneven surface, more intensive adsorption of reactants takes place, and the layer 
crystallization process can more easily occur than on flat parts of the substrate. As a consequence, light scattering can easily occur. Surfaces of commercial substrates can differ from each other. Hence, in this case, the transparency of the sample could be reduced despite the layer being amorphous. If a homogeneous nucleation process is present during the layer growth, the layer transparency would be reduced significantly.

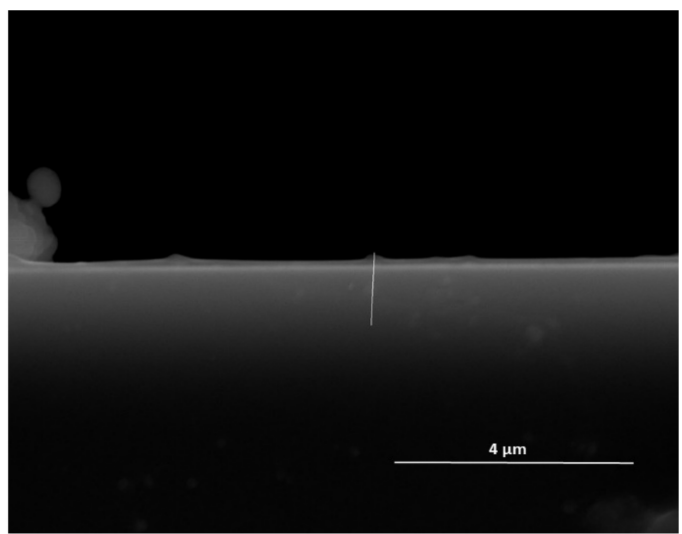

(a)

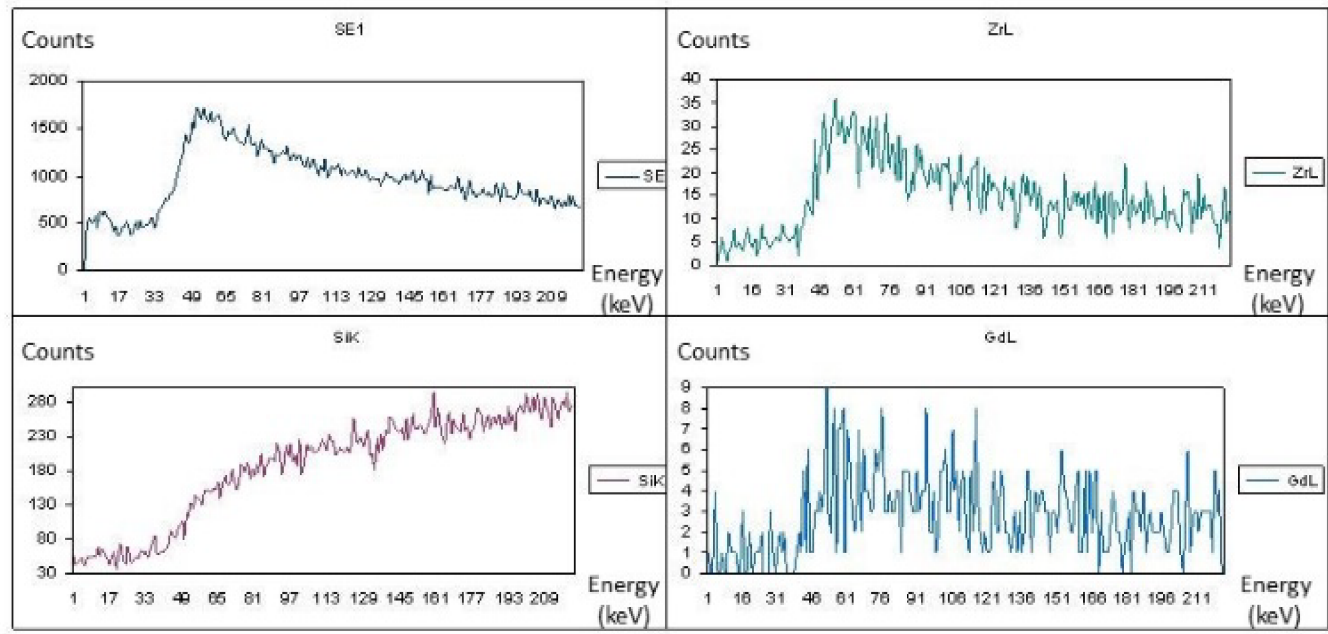

(b)

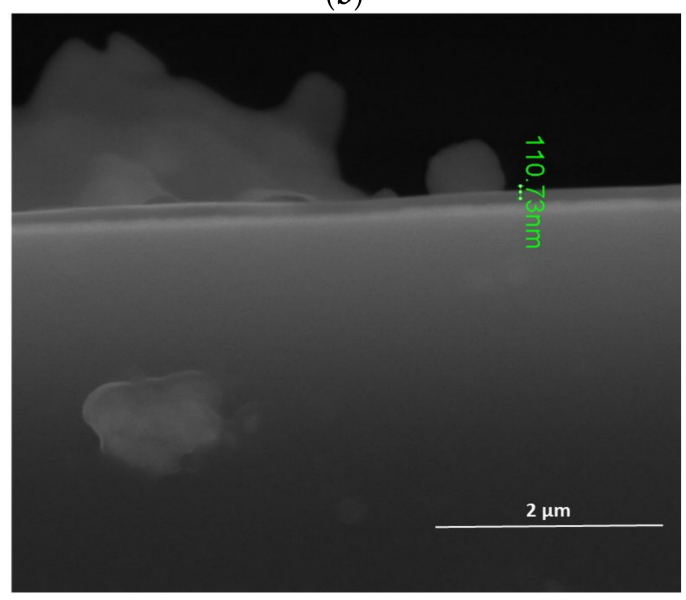

(c)

Figure 7. $\mathrm{ZrO}_{2}-\mathrm{Gd}_{2} \mathrm{O}_{3}$ layer deposited at $700{ }^{\circ} \mathrm{C}$ (a) and its cross-section (c) with linear EDS analysis (b). Molar content of $\mathrm{Gd}(\mathrm{tmhd})_{3}$ in the gas reaction mixture: $20 \%$. Synthesis time: $15 \mathrm{~min}$. 


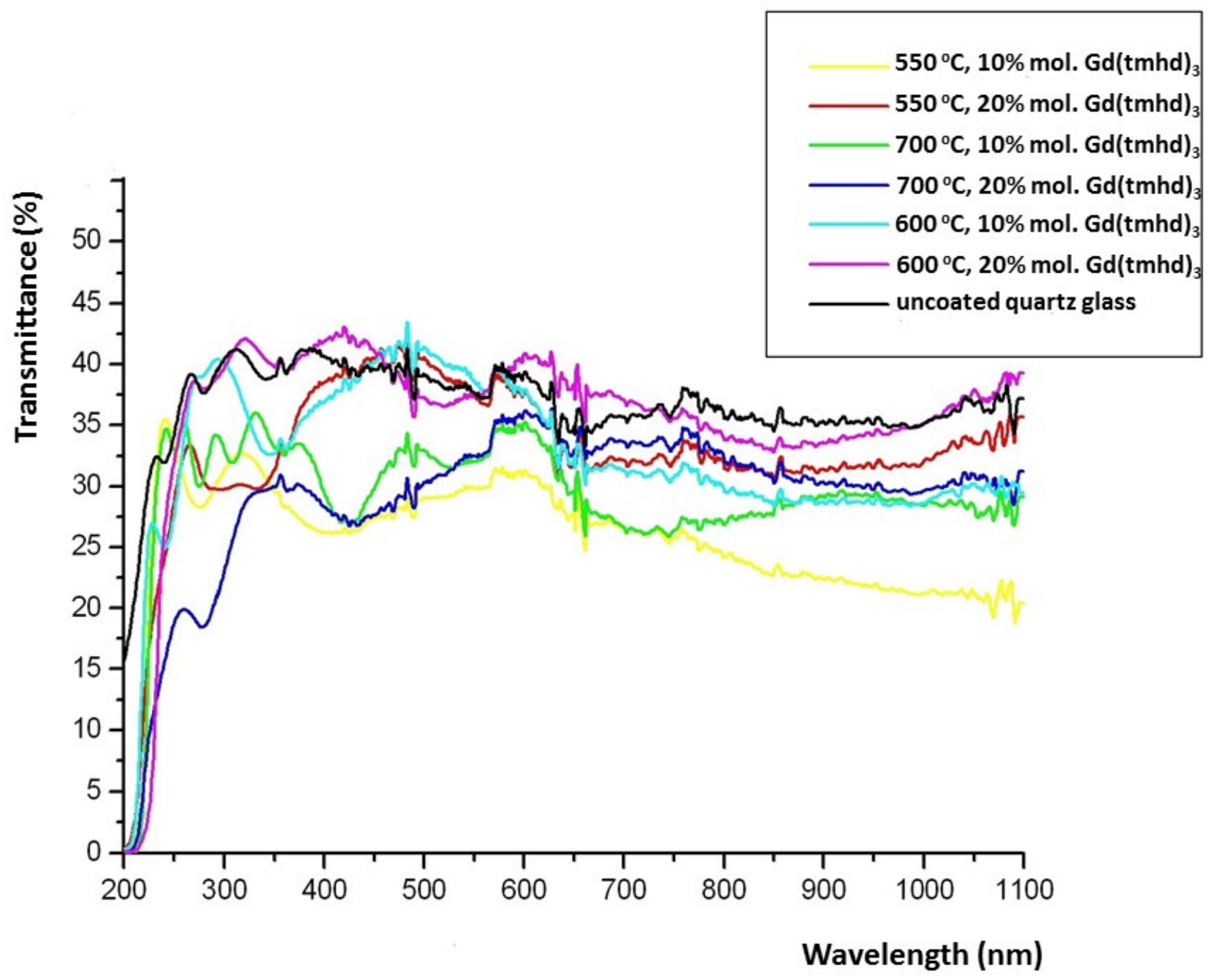

Figure 8. Transparency of the quartz glass covered with $\mathrm{ZrO}_{2}-\mathrm{Gd}_{2} \mathrm{O}_{3}$ layers deposited under various conditions and uncoated glass.

\section{Conclusions}

The presented results of our investigation into the deposition of $\mathrm{ZrO}_{2}-\mathrm{Gd}_{2} \mathrm{O}_{3}$ layers on the tubes made of quartz glass with the use of MOCVD showed that non-porous amorphous or crystalline layers can be deposited at low temperatures, i.e., $550-700{ }^{\circ} \mathrm{C}$. They are also uniform in thickness. $\mathrm{ZrO}_{2}-\mathrm{Gd}_{2} \mathrm{O}_{3}$ layers synthesized at temperatures of $600-700{ }^{\circ} \mathrm{C}$ exhibit crystallinity. When the synthesis temperature was lower and the molar content of $\mathrm{Gd}(\mathrm{tmhd})_{3}$ in the gas reaction mixture was higher $(20 \mathrm{~mol} . \%)$, the segregation of $\mathrm{Zr}^{4+}$ ions in the layers could be observed due to their smaller ionic radius compared to that of $\mathrm{Gd}^{3+}$ ions. As a consequence, the amount of $\mathrm{Gd}_{2} \mathrm{O}_{3}$ in the layer was different than expected. When the molar content of $\mathrm{Gd}(\mathrm{tmhd})_{3}$ in the gas reaction mixture was lower (10 mol.\%), there was a relationship between the composition of the gas reaction mixture used and that of the layers synthesized at temperatures of 550 and $700{ }^{\circ} \mathrm{C}$. It seems that the synthesis was also subsequently controlled by mass diffusion to the substrate. It is important to determine the transition temperature from the deposition controlled by the reaction rate on the substrate to that controlled by mass diffusion to the substrate from the gas phase. This temperature can be significantly reduced when the reactants are highly diluted in the carrier gases. 
At lower temperatures, the presence of aggregates was observed, irregularly distributed over the surface. When the synthesis temperature was higher, their numbers became higher and were more regularly distributed.

UV-Vis testing confirmed that homogeneous nucleation did not occur during the layer deposition. When the layer crystallization process became more advanced, a decrease in its transparency could be observed.

Funding: They were supported by subvention of the Polish State Ministry of Education and Science for AGH University of Science and Technology, Faculty of Materials Science and Ceramics (project no. 16.16.160.557).

Institutional Review Board Statement: Not applicable.

Informed Consent Statement: Not applicable.

Data Availability Statement: The data presented in this study are available upon request from the corresponding author.

Acknowledgments: Microstructural, structural and optical investigations were performed at the Faculty of Materials Science and Ceramics (AGH University of Science and Technology).

Conflicts of Interest: The author declares no conflict of interest.

\section{References}

1. Arachi, Y.; Sakai, H.; Yamamoto, O.; Takeda, Y.; Imanish, N. Electrical conductivity of the $\mathrm{ZrO}_{2}-\mathrm{Ln}_{2} \mathrm{O}_{3}$ ( $\left.\mathrm{Ln}=\mathrm{lanthanides}\right)$ system. Solid State Ion. 1999, 121, 133-139. [CrossRef]

2. Dutta, S.; Bhattacharya, S.; Agrawal, D.C. Electrical properties of $\mathrm{ZrO}_{2}-\mathrm{Gd}_{2} \mathrm{O}_{3}$ ceramics. Mater. Sci. Eng. B 2003, 100, 191-198. [CrossRef]

3. Kan, Y.; Li, S.; Wang, P.; Zhang, G.-J.; Van der Biest, O.; Vleugels, J. Preparation and conductivity of $\mathrm{Yb}_{2} \mathrm{O}_{3}-\mathrm{Y}_{2} \mathrm{O}_{3} \mathrm{and} \mathrm{Gd}_{2} \mathrm{O}_{3}-\mathrm{Y}_{2} \mathrm{O}_{3}$ co-doped zirconia ceramics. Solid State Ion. 2008, 179, 1531-1534. [CrossRef]

4. Anantharaman, A.P.; Dasari, H.P. Potential of pyrochlore structure materials in solid oxide fuel cell applications. Ceram. Int. 2021, 47, 4367-4388. [CrossRef]

5. Muccillo, E.N.S.; Rocha, R.A.; Muccillo, R. Preparation of $\mathrm{Gd}_{2} \mathrm{O}_{3}$-doped $\mathrm{ZrO}_{2}$ by polymericprecursor techniques. Mat. Lett. 2002, 53, 353-358. [CrossRef]

6. Madhusudhana, H.C.; Shobhadevi, S.N.; Nagabhushana, B.M.; Hari Krishna, R.; Murugendrappa, M.V.; Nagabhushana, H. Structural characterization and dielectric studies of $\mathrm{Gd}$ doped $\mathrm{ZrO}_{2}$ nano crystals synthesized by solution combustion method. Mater. Today Proc. 2018, 5, 21195-21204. [CrossRef]

7. Díaz-Guillén, J.A.; Fuentes, A.F.; Díaz-Guillén, M.R.; Almanza, J.M.; Santamaría, J.; León, C. The effect of homovalent A-site substitutions on the ionic conductivity of pyrochlore-type $\mathrm{Gd}_{2} \mathrm{Zr}_{2} \mathrm{O}_{7}$. J. Power Sources 2009, 186, 349-352. [CrossRef]

8. Anokhina, I.A.; Animitsa, I.E.; Voronin, V.I.; Vykhodets, V.B.; Kurennykh, T.E.; Molchanova, N.G.; Vylkov, A.I.; Dedyukhin, A.E.; Zaikov, Y.P. The structure and electrical properties of lithium doped pyrochlore $\mathrm{Gd}_{2} \mathrm{Zr}_{2} \mathrm{O}_{7}$. Ceram. Int. 2021, 47, $1949-1961$. [CrossRef]

9. Xie, X.; Kumar, R.V.; Sun, J.; Henson, L.J. Structure and conductivity of yttria-stabilized zirconia co-doped with Gd ${ }_{2} \mathrm{O}_{3}$ : $\mathrm{A}$ combined experimental and molecular dynamics study. J. Power Sources 2010, 195, 5660-5665. [CrossRef]

10. Moztarzadeh, F.; Tahriri, M.; Alavi, S.H.; Ashuri, M.; Shahmoradi, S.R. Evaluation of the electrical properties of $\mathrm{Gd}_{2} \mathrm{O}_{3}$-stabilized $\mathrm{ZrO}_{2}$ at two representative temperatures. J. Ceram. Process. Res. 2014, 15, 408-410.

11. Agarkova, E.A.; Borik, M.A.; Volkova, T.V.; Kulebyakin, A.V.; Kuritsyna, I.E.; Lomonova, E.E.; Milovich, F.O.; Myzina, V.A.; Ryabochkina, P.A.; Tabachkova, N.Y. Ionic conductivity, phase composition, and local defect structure of $\mathrm{ZrO}_{2}-\mathrm{Gd}_{2} \mathrm{O}_{3}$ system solid solution crystals. J. Solid State Electrochem. 2019, 23, 2619-2626. [CrossRef]

12. Li, S.; Xu, S.; Wang, X.; Wang, D.; Goodman, B.A.; Hong, X.; Deng, W. Optical properties of gadolinia-doped cubic yttria stabilized zirconia single crystals. Ceram. Int. 2021, 47, 3346-3353. [CrossRef]

13. Wang, X.J.; Xiao, H.Y.; Zu, X.T.; Weber, W.J. Study of cerium solubility in $\mathrm{Gd}_{2} \mathrm{Zr}_{2} \mathrm{O}_{7}$ by DFT + U calculations. J. Nucl. Mater. 2011, 419, 105-111. [CrossRef]

14. Rahaman, M.N.; Gross, J.R.; Dutton, R.E.; Wang, H. Phase stability, sintering, and thermal conductivity of plasma-sprayed $\mathrm{ZrO}_{2}-\mathrm{Gd}_{2} \mathrm{O}_{3}$ compositions for potential thermal barrier coating applications. Acta Mater. 2006, 54, 1615-1621. [CrossRef]

15. Portinha, A.; Teixeira, V.; Carneiro, J.; Costa, M.F.; Barradas, N.P.; Sequeira, A.D. Stabilization of $\mathrm{ZrO}_{2} \mathrm{PVD}_{\text {coatings with Gd }} \mathrm{O}_{3}$. Surf. Coat. Technol. 2004, 188-189, 107-115. [CrossRef]

16. Carpio, P.; Salvador, M.D.; Borrell, A.; Sánchez, E. Thermal behaviour of multilayer and functionally-graded $\mathrm{YSZ}_{2} / \mathrm{Gd}_{2} \mathrm{Zr}_{2} \mathrm{O}_{7}$ coatings. Ceram. Int. 2017, 43, 4048-4054. [CrossRef]

17. Yang, G.; Wang, D.; Zhang, C.; Cao, J.; Du, Y.; Liu, B.; Chen, H.; Cui, Y.; Luo, H.; Gao, Y. Fabrication of gadolinium zirconate films by laser CVD. Ceram. Int. 2019, 45, 4926-4933. [CrossRef] 
18. Zhang, C.; Fan, Y.; Zhao, J.; Yang, G.; Chen, H.; Zhang, L.; Gao, Y.; Liu, B. Corrosion resistance of non-stoichiometric gadolinium zirconate fabricated by laser-enhanced chemical vapor deposition. J. Adv. Ceram. 2021, 10, 520-528. [CrossRef]

19. Guo, L.; Guo, H.; Gong, S.; Xu, H. Improvement on the phase stability, mechanical properties and thermal insulation of $\mathrm{Y}_{2} \mathrm{O}_{3}-$ stabilized $\mathrm{ZrO}_{2}$ by $\mathrm{Gd}_{2} \mathrm{O}_{3}$ and $\mathrm{Yb}_{2} \mathrm{O}_{3}$ co-doping. Ceram. Int. 2013, 39, 9009-9015. [CrossRef]

20. Mahade, S.; Curry, N.; Björklund, S.; Markocsan, N.; Nylén, P.; Vaßen, R. Functional performance of Gd $\mathrm{Gr}_{2} \mathrm{O}_{7} / \mathrm{YSZ}_{\text {multi-layered }}$ thermal barrier coatings deposited by suspension plasma spray. Surf. Coat. Technol. 2017, 318, 208-216. [CrossRef]

21. Keyvani, A.; Saremi, M.; Heydarzadeh Sohi, M.; Valefi, Z. A comparison on thermomechanical properties of plasma-sprayed conventional and nanostructured YSZ TBC coatings in thermal cycling. J. Alloys Compd. 2012, 541, 488-494. [CrossRef]

22. Čelko, L.; Jech, D.; Tkachenko, S.; Komarov, P.; Remešová, M.; Slámečka, K.; Ctibor, P. Failure of Gadolinium Zirconate and Yttria Stabilized Zirconia Thermal Barrier coatings subjected to high temperature calcia-magnesia-alumino-silicate attack. Procedia Struct. Integr. 2019, 23, 360-365. [CrossRef]

23. Bobzin, K.; Zhao, L.; Öte, M.; Linke, T.F. Deposition and characterization of thermal barrier coatings of $\mathrm{ZrO}_{2}-4 \mathrm{~mol}^{2} \% \mathrm{Y}_{2} \mathrm{O}_{3}-$ $1 \mathrm{~mol} . \% \mathrm{Gd}_{2} \mathrm{O}_{3}-1 \mathrm{~mol} \% \mathrm{Yb}_{2} \mathrm{O}_{3}$. Surf. Coat. Technol. 2015, 268, 205-208. [CrossRef]

24. Zhao, Z.-T.; Guo, R.-F.; Mao, H.-R.; Shen, P. Effect of components on the microstructures and properties of rare-earth zirconate ceramics prepared by ultrafast high-throughput sintering. J. Eur. Ceram. Soc. 2021, 41, 5768-5773. [CrossRef]

25. Schmitt, M.P.; Stokes, J.L.; Gorin, B.L.; Rai, A.K.; Zhu, D.; Eden, T.J.; Wolfe, D.E. Effect of Gd content on mechanical properties and erosion durability of sub-stoichiometric $\mathrm{Gd}_{2} \mathrm{Zr}_{2} \mathrm{O}_{7}$. Sur. Coat. Technol. 2017, 313, 177-183. [CrossRef]

26. Schulz, U.; Nowotnik, A.; Kunkel, S.; Reiter, G. Effect of processing and interface on the durability of single and bilayer 7YSZ/gadolinium zirconate EB-PVD thermal barrier coatings. Surf. Coat. Technol. 2020, 381, 125107. [CrossRef]

27. Wang, Y.; Zhou, C. Effect of $\mathrm{Gd}_{2} \mathrm{O}_{3}$ on the microstructure and thermal properties of nanostructured thermal barrier coatings fabricated by air plasma spraying. Prog. Nat. Sci. Mater. Int. 2016, 26, 362-367. [CrossRef]

28. Guo, L.; Guo, H.; Peng, H.; Gong, S. Thermophysical properties of $\mathrm{Yb}_{2} \mathrm{O}_{3}$ doped $\mathrm{Gd}_{2} \mathrm{Zr}_{2} \mathrm{O}_{7}$ and thermal cyclingdurability of $\left(\mathrm{Gd}_{0.9} \mathrm{Yb}_{0.1}\right)_{2} \mathrm{Zr}_{2} \mathrm{O}_{7} / \mathrm{YSZ}$ thermal barrier coatings. J. Eur. Ceram. Soc. 2014, 34, 1255-1263. [CrossRef]

29. Wu, J.; Padture, N.P.; Klemens, P.G.; Gell, M.; Garcia, E.; Miranzo, P.; Osendi, M.I. Thermal conductivity of ceramics in the $\mathrm{ZrO}_{2}-\mathrm{GdO}_{1.5}$ system. J. Mater. Res. 2002, 17, 3193-3200. [CrossRef]

30. Doleker, K.M.; Karaoglanli, A.C. Comparison of oxidation behavior of $\mathrm{YSZ}$ and $\mathrm{Gd}_{2} \mathrm{Zr}_{2} \mathrm{O}_{7}$ thermal barrier coatings (TBCs). Surf. Coat. Technol. 2017, 318, 198-207. [CrossRef]

31. Padture, N.P.; Gel, M.; Jordan, E.H. Thermal barrier coatings for gas-turbine engine applications. Science 2002, 296, 280-284. [CrossRef] [PubMed]

32. Zhang, Y.; Guo, L.; Zhao, X.; Wang, C.; Ye, F. Toughening effect of $\mathrm{Yb}_{2} \mathrm{O}_{3}$ stabilized $\mathrm{ZrO}_{2}$ doped in $\mathrm{Gd}_{2} \mathrm{Zr}_{2} \mathrm{O}_{7}$ ceramic for thermal barrier coatings. Mater. Sci. Eng. A 2015, 648, 385-391. [CrossRef]

33. Vaßen, R.; Jarligo, M.O.; Steinke, T.; Mack, D.E.; Stöver, D. Overview on advanced thermal barrier coatings. Surf. Coat. Technol. 2010, 205, 938-942. [CrossRef]

34. Jiang, K.; Liu, S.; Wang, X. Phase stability and thermal conductivity of nanostructured tetragonal yttria-stabilzed zirconia thermal barrier coatings deposited by air-plasma spraying. Ceram. Int. 2017, 43, 12633-12640. [CrossRef]

35. Kwatera, A. Models of the processes at the substrate surface in the CVD method. Ceram. Int. 1991, 17, 11-23. [CrossRef]

36. Sawka, A.; Kwatera, A.; Andreasik, P. Deposition and characterization of ceria layers using the MOCVD method. Mat. Lett. 2017, 204, 39-41. [CrossRef]

37. Sawka, A.; Kwatera, A. Deposition of gadolinia-doped ceria layers by MOCVD at low temperatures. Ceram. Int. 2018, 44, 6257-6264. [CrossRef]

38. Kwatera, A. Carbon-doped $\alpha-\mathrm{Al}_{2} \mathrm{O}_{3}$ films synthesized on cemented carbide tools by the metal organic LPCVD technique. Thin Solid Films 1991, 200, 19-32. [CrossRef]

39. Sawka, A.; Kwatera, A. Model research on synthesis of $\mathrm{Al}_{2} \mathrm{O}_{3}-\mathrm{C}$ layers by MOCVD. Arch. Metall. Mater. 2015, 60, 1125-1128. [CrossRef]

40. Sawka, A.; Kwatera, A. Preparation of $\mathrm{ZrO}_{2}-\mathrm{Y}_{2} \mathrm{O}_{3}$ layers at low temperatures by MOCVD under atmospheric and reduced pressure. Mat. Sci. Eng. B 2018, 228, 142-152. [CrossRef]

41. Sawka, A.; Kwatera, A. Synthesis of non-porous and nanocrystalline lanthana-doped zirconia layers by MOCVD method at low temperatures and pressure. Ceram. Int. 2019, 45, 12795-12805. [CrossRef] 